\title{
A GRADED-GAP X-RAY DETECTOR WITH CHARGE AVALANCHE MULTIPLICATION
}

\author{
L. Dapkus, V. Jasutis, V. Jucienė, J. Požela, K. Požela, and A. Šilėnas \\ Semiconductor Physics Institute, A. Goštauto 11, LT-01108 Vilnius, Lithuania \\ E-mail:pozela@pfi.lt
}

Received 31 October 2006

\begin{abstract}
Current response of graded-gap $\mathrm{Al}_{x} \mathrm{Ga}_{1-x} \mathrm{As} \mathrm{X}$-ray detector is experimentally investigated. An increase in sensitivity of the detectors is achieved using a charge avalanche multiplication effect in a narrow region of a $p$ - $\mathrm{Al}_{x} \mathrm{Ga}_{1-x} \mathrm{As} / n$-GaAs heterojunction. The graded-gap $\mathrm{Al}_{x} \mathrm{Ga}_{1-x} \mathrm{As} \mathrm{X}$-ray detector with charge avalanche multiplication has been developed. The sensitivity of this new type detector at a bias voltage $U=1.5 \mathrm{~V}$ reaches $2.5 \mathrm{~A} / \mathrm{W}$. That is fifty times higher in comparison with the sensitivity of the detector without charge multiplication $(U=0)$.
\end{abstract}

Keywords: X-ray detectors, graded-gap $\mathrm{Al}_{x} \mathrm{Ga}_{1-x}$ As structures

PACS: $07.85 . \mathrm{Fv}, 73.40 . \mathrm{Kp}$, 42.79.Pw

\section{Introduction}

The important advantage of X-ray detectors based on graded-gap $p$ - $\mathrm{Al}_{x} \mathrm{Ga}_{1-x} \mathrm{As} / n$-GaAs heterostructures is charge collection without application of any bias voltage $[1,2]$. A charge generated by X-ray radiation in the $\mathrm{Al}_{x} \mathrm{Ga}_{1-x} \mathrm{As}$ layer is collected by a graded-gap field at the $p-n$-junction region. In order to increase a current response of the graded-gap $\mathrm{Al}_{x} \mathrm{Ga}_{1-x} \mathrm{As} \mathrm{X}$-ray detector, the charge avalanche multiplication effect in a narrow region of $p-\mathrm{Al}_{x} \mathrm{Ga}_{1-x} \mathrm{As} /$ $n$-GaAs heterojunction was proposed in [2]. When an external bias voltage is applied in a reverse direction, the voltage is concentrated not in a bulk of the $\mathrm{Al}_{x} \mathrm{Ga}_{1-x}$ As layer, but in the $p^{+}-n^{-}$-junction region. At a sufficiently large reverse voltage, the charge collected at the $p^{+}-n^{-}$-junction is multiplied due to impact ionization in a high electric field. The effect of charge avalanche multiplication in a detector current response was observed in [2]. However, due to heating of the $p-n$-junction by the current, the longduration effects of reverse current relaxation were observed. These effects do not allow to use the device for $\mathrm{X}$-ray radiation detection.

In this paper, the possibilities to exclude a part of current response to the $\mathrm{X}$-ray irradiation from the longduration effects of reverse current changes are considered.

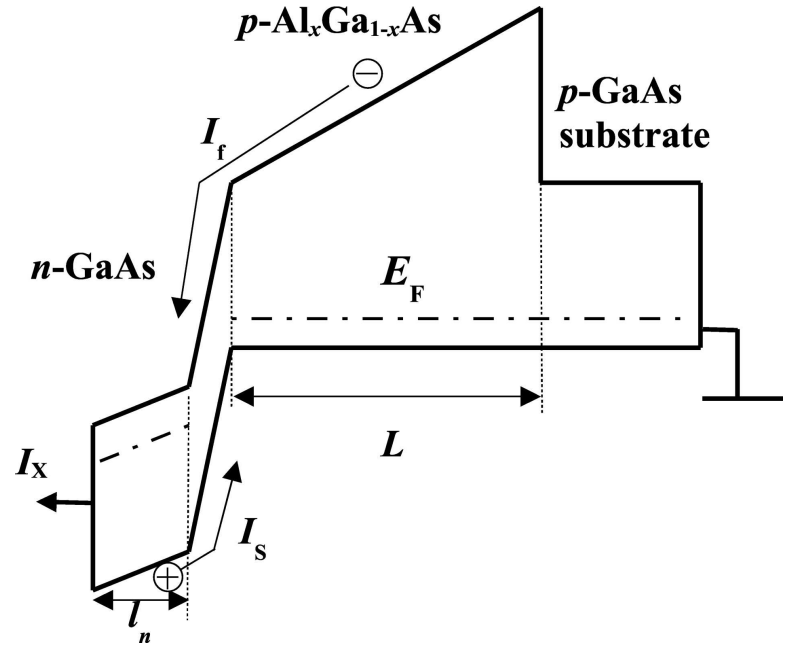

Fig. 1. Schematic band diagram of a $n^{-}-\mathrm{GaAs} / p^{+}-\mathrm{Al}_{x} \mathrm{Ga}_{1-x} \mathrm{As}$ heterostructure grown on a $p$-GaAs substrate with an applied reverse voltage. $I_{f}$ denotes the electron flow in a graded-gap field, $I_{S}$ indicates the $p-n$-junction reverse current.

The following structure was investigated. A highdoped $\left(p^{+}=10^{18} \mathrm{~cm}^{-3}\right)$ graded-gap $p^{+}-\mathrm{Al}_{x} \mathrm{Ga}_{1-x} \mathrm{As}$ layer of thickness $L=20 \mu \mathrm{m}$ on the $p^{+}$-GaAs substrate was grown by a liquid-phase epitaxy. The $\mathrm{Al}_{x}$ concentration was changed from $x=0.4$ at the substrate to $x=0$ at the narrow-gap side. On the top of the structure, a thin $\left(l_{n}<10^{-4} \mathrm{~cm}\right)$ low-doped $\left(n=10^{16} \mathrm{~cm}^{-3}\right)$ $n$-GaAs layer was grown. The plane area of the detector was $S=1 \times 2 \mathrm{~mm}^{2}$. Figure 1 shows the schematic band diagram of the heterostructure under study. 


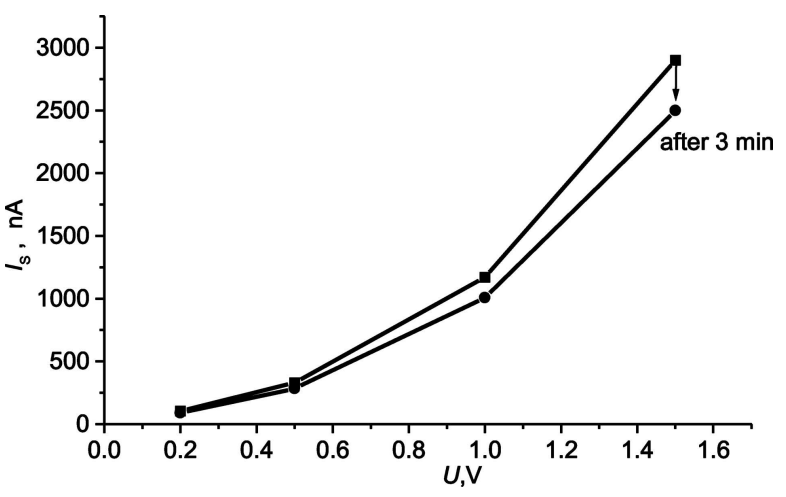

Fig. 2. Reverse current $I_{\mathrm{S}}$ through the $p^{+}-\mathrm{Al}_{x} \mathrm{Ga}_{1-x} \mathrm{As} / n^{-}$-GaAs heterojunction as a function of voltage $U$. A time interval between the $I_{\mathrm{S}}$ measurements at a given $U$ is $3 \mathrm{~min}$.

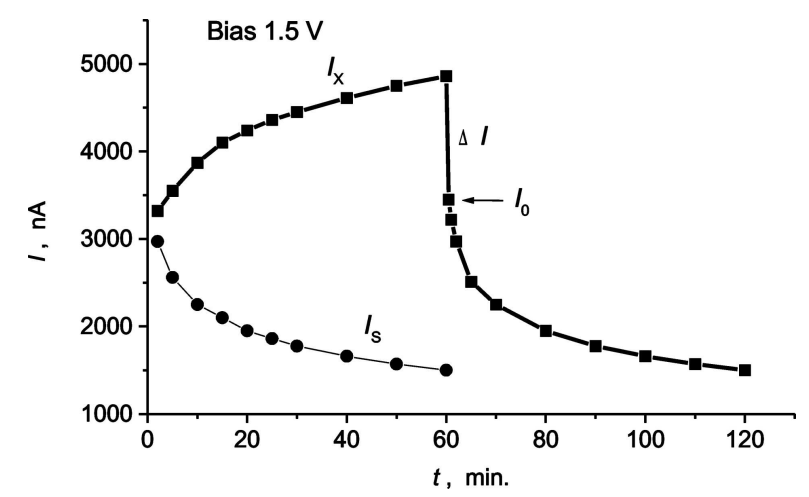

Fig. 3. Long-duration relaxation of the detector reverse current $I$. $I_{\mathrm{S}}$ is the reverse current in the absence of X-ray radiation, $I_{\mathrm{X}}$ is the reverse current with $\mathrm{X}$-ray radiation, and $I_{0}$ is the reverse current when $\mathrm{X}$-ray radiation was turned off. The $\mathrm{X}$-ray power density at the detector surface was $3.7 \cdot 10^{-5} \mathrm{~W} / \mathrm{cm}^{2}$.

\section{Long-duration relaxation of reverse current}

The dependence of the reverse current $I_{\mathrm{S}}$ through the structure on a voltage $U$ is shown in Fig. 2. The reverse current increases due to avalanche ionization of electron-hole pairs in high $p-n$-junction field. At a voltage of $1.5 \mathrm{~V}$, the current increases tens of times.

At the same time, with an increase of the reverse current $I_{\mathrm{S}}$, the long-duration process of current change in time is observed. The decrease of $I_{\mathrm{S}}$ after $3 \mathrm{~min}$ following the observation is shown in Fig. 2.

Figure 3 shows that a slow decrease to a new equilibrium state goes on for a few tens of minutes. We associate such a slow relaxation of the reverse current with a local heating of the $p-n$-junction region, mainly in the $n^{-}$-GaAs layer with a thickness smaller than the hole diffusion length. In the heated thin $n^{-}$GaAs layer, slow changes of many parameters in time, such as diffusion coefficient, electron-hole recombination time, surface recombination rate, and others are responsible for the long-duration current decrease. Note that for the current through the thin $n^{-}$-GaAs layer, the minority carrier (hole) current is responsible.

Upon turning on the $\mathrm{X}$-ray radiation, the current through the structure increases sharply due to injection and multiplication of carriers generated by ionizing radiation and those collected from the graded-gap crystal part, and then slowly increases in time (Fig. 3). As it is seen, the injection of non-equilibrium additional majority carriers into the $n$-GaAs part from the graded-gap part leads to a change of character of current relaxation from the decrease in the absence of X-rays to the increase under X-ray radiation.

A total current through the graded-gap structure $p^{+}-\mathrm{Al}_{x} \mathrm{Ga}_{1-x} \mathrm{As} / n^{-}-\mathrm{GaAs}$ under $\mathrm{X}$-ray radiation and at an applied bias, sufficient for impact ionization, is equal to

$$
I_{\mathrm{X}}=I_{\mathrm{f}}+I_{\mathrm{Sf}}
$$

where $I_{\mathrm{f}}$ is the current of avalanche-multiplied collected charge generated by ionizing radiation in the $p^{+}-\mathrm{Al}_{x} \mathrm{Ga}_{1-x}$ As layer, and $I_{\mathrm{Sf}}$ is the avalanche reverse current when $I_{\mathrm{f}}$ exists. The current $I_{\mathrm{f}}$ is the current response to $X$-ray radiation, i. e. that useful signal which we wish to exclude from the long-duration relaxation of total current $I_{\mathrm{X}}$.

At turning off the $\mathrm{X}$-ray radiation, the current through the structure decreases sharply by a value $I_{\mathrm{f}}$ and then decays slowly in the same way as it was in the absence of X-ray radiation (Fig. 3).

It is essential that $I_{\mathrm{f}}$ - the value of the current change at turning-off the X-ray radiation - does not depend on the time moment of turning-off. That is, independently of a long-duration and intricate relaxation of saturated total current, the difference between time-dependent currents,

$$
\Delta I=I_{\mathrm{X}}(t)-I_{\mathrm{S}}(t)=I_{\mathrm{f}},
$$

does not depend on time. $\Delta I$ is the current response $I_{\mathrm{f}}$ to $\mathrm{X}$-ray radiation.

To confirm this fact, the simultaneously measured currents $I_{\mathrm{X}}$, with X-ray radiation, and the reverse current $I_{0}$ without it, as functions of X-ray radiation absorbed in the structure, $P_{\text {abs }}$, are shown in Fig. 4. The measurements repeated after 3 min intervals are also shown. One can see that in spite of remarkable changes of current values registered with radiation and without it after a 3 min time interval, the values of difference $\Delta I=I_{\mathrm{X}}-I_{0}$ between these currents do not depend on time and can be defined as a value corresponding to $\mathrm{X}$-ray radiation power. 


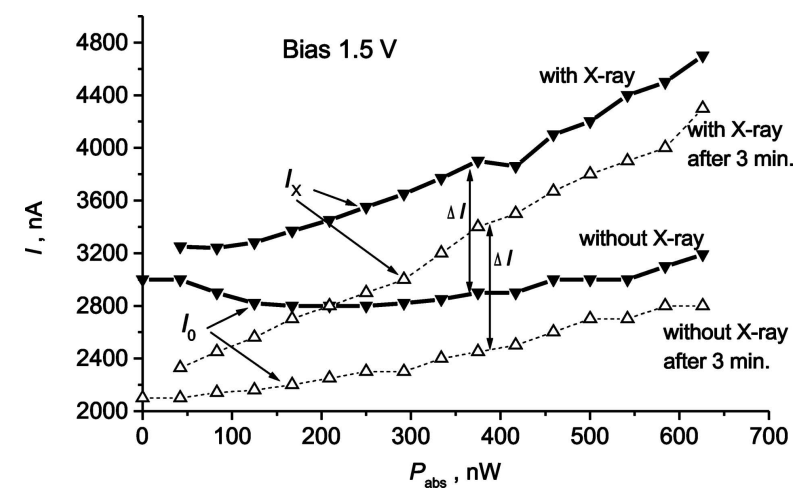

Fig. 4. Simultaneously measured currents: $I_{\mathrm{X}}$ at X-ray radiation and $I_{0}$, when the radiation was turned off for a short time, as functions of X-ray absorbed power, $P_{\text {abs }}$ (full triangles). The measurements repeated after $3 \mathrm{~min}$ are shown by empty triangles. The bias voltage was $1.5 \mathrm{~V}$.

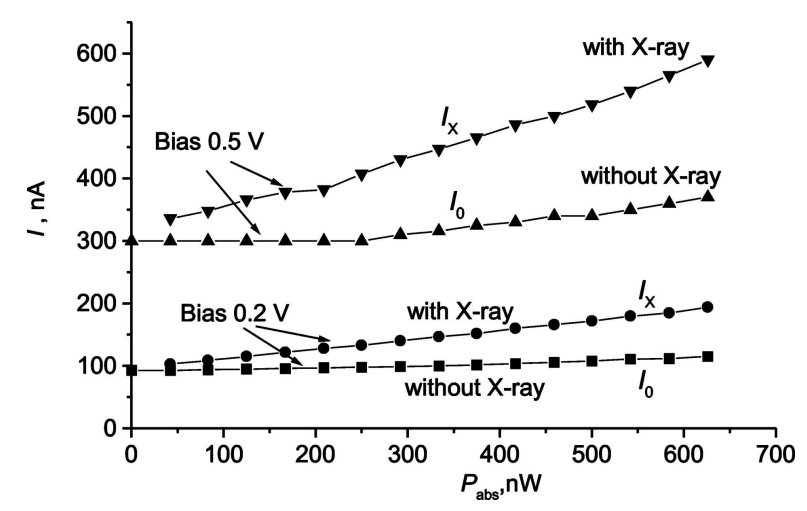

Fig. 5. Simultaneously measured currents: $I_{\mathrm{X}}$ at X-ray radiation and $I_{0}$, when the radiation was turned off for a short time, as functions of X-ray absorbed power, $P_{\text {abs }}$, at bias voltages of 0.2 and $0.5 \mathrm{~V}$.

Figure 5 shows the analogical measurements at bias voltages of 0.2 and $0.5 \mathrm{~V}$. The current change without $\mathrm{X}$-ray radiation on a radiation power scale is caused by a time change in the measurement process.

Thus, it is shown that, in spite of an intricate character of long-duration relaxation processes taking place in the X-ray detector with charge avalanche multiplication, the current response to X-ray radiation does not depend on time and can be separated as a difference between the total current at X-ray radiation and the current without the radiation at any moment of time.

\section{Sensitivity of the detector with charge avalanche multiplication}

To measure the sensitivity of the detector, an X-ray tube with a $\mathrm{Cu}$ anode has been used as an $\mathrm{X}$-ray radiation source with characteristic radiation of $8 \mathrm{keV}$. The anode voltage was $U_{\mathrm{A}}=30 \mathrm{kV}$. The output X-ray radiation power was controlled by varying the anode cur-

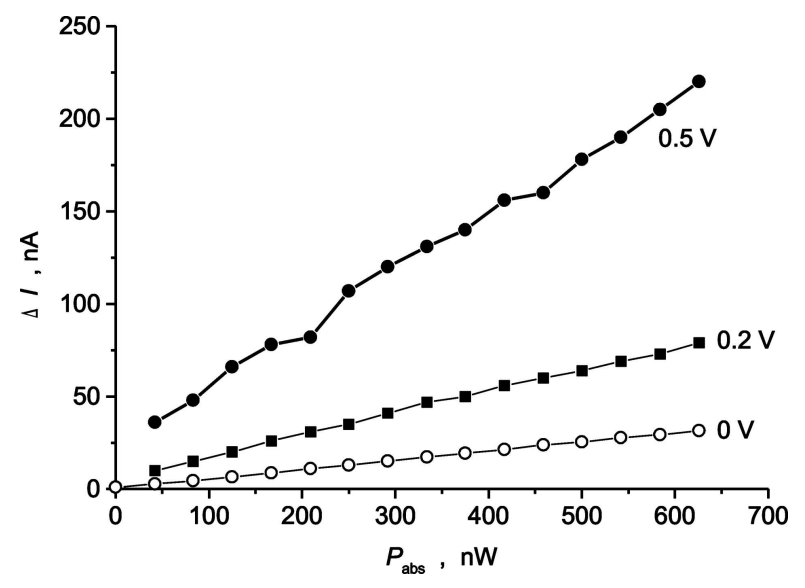

Fig. 6. Current response $\Delta I$ of the detector as a function of X-ray absorbed power $P_{\text {abs }}$ at different bias voltages.

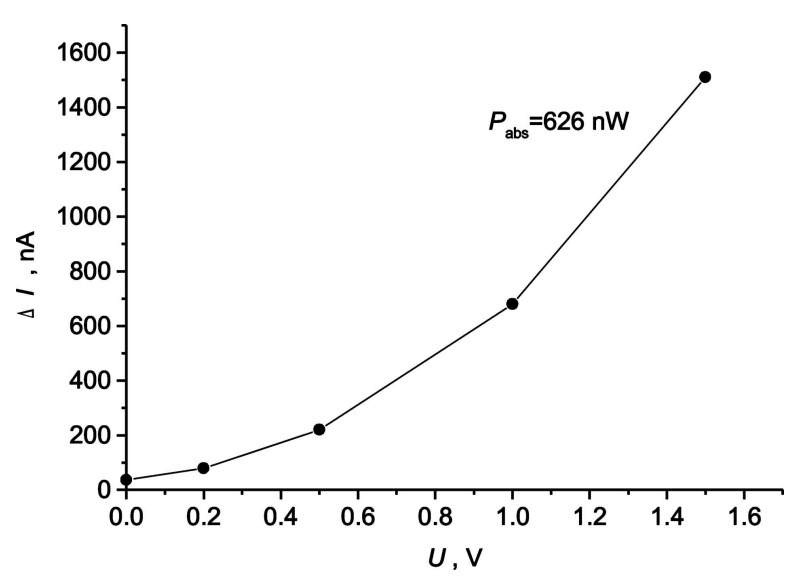

Fig. 7. Current response $\Delta I$ of the detector as a function of bias voltage $U$ at $P_{\text {abs }}=626 \mathrm{nW}$.

rent $I_{\mathrm{A}}$ from 1 to $30 \mathrm{~mA}$. The density of $\mathrm{X}$-ray radiation on the detector surface was $3.7 \cdot 10^{-5} \mathrm{~W} / \mathrm{cm}^{2}$ at $U_{\mathrm{A}}=$ $30 \mathrm{kV}$ and $I_{\mathrm{A}}=20 \mathrm{~mA}$.

The dependences of the current response $\Delta I=I_{\mathrm{f}}$ on the absorbed X-ray radiation power at the applied voltages of 0.2 and $0.5 \mathrm{~V}$, and without the bias, are shown in Fig. 6. The current multiplication effect takes place already at $0.2 \mathrm{~V}$. In spite of complexity of an impact ionization process, a nearly linear dependence of the avalanche current on the absorbed power is observed at all bias voltages.

The sensitivity of the detector,

$$
g=\frac{\Delta I}{\Delta P_{\mathrm{abs}}},
$$

is determined by the bias voltage. At a constant absorbed X-ray power, the current response $\Delta I=I_{\mathrm{f}}$ sharply increases with the applied voltage (Fig. 7). Correspondingly, the detector sensitivity increases strongly when the applied voltage increases. In the absence of the bias $(U=0)$, the sensitivity of the graded- 
gap detector $(g=0.05 \mathrm{~A} / \mathrm{W})$ coincides with the sensitivity of conventional detectors. At the bias voltage $U=1.5 \mathrm{~V}$, due to avalanche multiplication of the collected charge, the detector sensitivity increases by a factor of 50 and reaches $g=2.5 \mathrm{~A} / \mathrm{W}$.

The sensitivity of conventional X-ray detectors based on different semiconductors is determined by the threshold energy required for an electron-hole pair generation and by the charge collection efficiency. The average threshold energy for different materials used in conventional X-ray detectors varies from $2.98 \mathrm{eV}$ for $\mathrm{Ge}$ to $7.68 \mathrm{eV}$ for $\mathrm{PbJ}_{2}$ [3]. Consequently, the maximum sensitivity of conventional detectors (for $100 \%$ charge collection efficiency), evaluated in the same way as in [4], is in the range of $0.13-0.34 \mathrm{~A} / \mathrm{W}_{\mathrm{abs}}$. So, the sensitivity of the graded-gap $\mathrm{Al}_{x} \mathrm{Ga}_{1-x} \mathrm{As} \mathrm{X}$-ray detectors with charge avalanche multiplication exceeds ten times the sensitivity of conventional detectors.

\section{Conclusions}

1. The difference between the total current, relaxing in time at X-ray radiation, and the current, when the radiation is turned off for a short time, determines the independent on time current response of the graded-gap $\mathrm{Al}_{x} \mathrm{Ga}_{1-x} \mathrm{As} \mathrm{X}$-ray detector with charge avalanche multiplication to the X-ray absorbed power in the graded-gap structure.

2. Because of avalanche multiplication of the collected charge, the detector sensitivity markedly exceeds the sensitivity of conventional detectors. The sensitivity reaches $2.5 \mathrm{~A} / \mathrm{W}$ at bias voltage of $1.5 \mathrm{~V}$.

\section{References}

[1] J. Požela, K. Požela, A. Šilėnas V. Jasutis, L. Dapkus, A. Kindurys, and V. Juciené, A graded-gap detector of ionizing radiation, Semicond. 36, 116-120 (2002) [in Russian: Fiz. Tekh. Poluprovodn. 36, 124128 (2002)].

[2] A. Silenas, K. Pozela, L. Dapkus, V. Jasutis, V. Juciene, J. Pozela, and K.M. Smith, Graded-gap $\mathrm{Al}_{x} \mathrm{Ga}_{1-x} \mathrm{As}$ $\mathrm{X}$-ray detector with collected charge multiplication, Nucl. Instrum. Methods A 509, 30-33 (2003).

[3] Yu.K. Akimov, O.V. Ignat'ev, A.I. Kalinin, and V.F. Kushniruk, Poluprovodnikovye Detektory $v$ Eksperimental'noi Fizike (Energoatomizdat, Moscow, 1989), p. 104 [in Russian].

[4] A. Silenas, J. Pozela, K.M. Smith, K. Pozela, V. Jasutis, L. Dapkus, and V. Juciene, Non-uniformly doped graded-gap $\mathrm{Al}_{x} \mathrm{Ga}_{1-x} \mathrm{As} \mathrm{X}$-ray detectors with high photovoltaic response, Nucl. Instrum. Methods A 487, 54-59 (2002).

\title{
VARIZONINIS RENTGENO SPINDULIUOTĖS DETEKTORIUS SU GRIŪTINIU KRŪVIO DAUGINIMU
}

\author{
L. Dapkus, V. Jasutis, V. Jucienė, J. Požela, K. Požela, A. Šilènas
}

Puslaidininkiu fizikos institutas, Vilnius, Lietuva

\section{Santrauka}

Eksperimentiškai tirtas varizoniniu $\mathrm{Al}_{x} \mathrm{Ga}_{1-x} \mathrm{As}$ Rentgeno spinduliuotès detektorių srovès atsakas. Siekiant padidinti detektoriu jautrị, panaudotas krūvininkų griūtinio dauginimo efektas $p-\mathrm{Al}_{x} \mathrm{Ga}_{1-x} \mathrm{As} / n$-GaAs sandūros srityje. Sukurtas varizoninis
Rentgeno spinduliuotès detektorius su griūtiniu krūvio dauginimu. Naujo detektoriaus srovės atsako jautris, esant postūmio įtampai $U=1,5 \mathrm{~V}$, siekia $2,5 \mathrm{~A} / \mathrm{W}$. Šis dydis yra apie $50 \mathrm{kartų} \mathrm{didesnis}$ už Rentgeno spinduliuotės detektorių, kuriuose nèra krūvio dauginimo $(U=0)$, jautrị. 